\title{
Pol Arch Med Wewn at the end of 2014
}

\author{
Anetta Undas \\ Editor-in-Chief, Polish Archives of Internal Medicine
}

Correspondence to:

Prof. Anetta Undas, MD, PhD, Instytut Kardiologii, Uniwersytet Jagielloński, Collegium Medicum, ul. Prądnicka 80, 31-202 Kraków, Poland, phone: + 48-12-614-30-04 fax: +48-12-423-39-00, e-mail: mmundas@cyf-kr.edu.p Received: December 10, 2014. Accepted: December 10, 2014. Conflict of interest: none declared. Pol Arch Med Wewn. 2014; 124 (12): 653-656

Copyright by Medycyna Praktyczna, Kraków 2014
In 2014, the peer-reviewed open-access journal, Polish Archives of Internal Medicine (Polskie Archiwum Medycyny Wewnętrznej, Pol Arch Med Wewn), has published 69 full-length articles, including 49 original papers and 20 review articles. Of this rapidly growing number of papers submitted to our journal, we selected $24 \%$ in a genuine belief that the journal's contents will be of interest to internists, in particular those involved in clinical and basic research. The recent changes in our journal included the introduction of new sections-Clinical Images (in January 2013) and Research Letters (in October 2014).

As every journal, the Pol Arch Med Wewn has editorial requirements uniquely suited to its purposes. Based on a recent experience, it should be stressed again that the authors of any piece of work submitted to our journal should become familiar with the Instructions for Authors and should closely follow those instructions to increase the chances for their paper to be considered for review and publication. Given a remarkable number of errors detected immediately after the initial submission of a manuscript, we now strictly adhere to our instructions and send back all flawed papers to their authors before forwarding the paper for peer-review. A well-written manuscript, which follows the journal's guidelines, means faster reviewing process and final acceptance of the paper.

Since September 2014, all authors of the original papers should include a contribution statement on submission in the online editorial system as well as in the manuscript following the Acknowledgments section. This set of information could be of importance while the authors declare their involvement in the preparation of the papers during the academic carrier, particularly in Poland. It should be reminded that the authorship credit should be based on 1) substantial contribution to the study concept and design, acquisition of data, and interpretation of data; 2) drafting the article or revising it critically for important intellectual content; and 3) final approval of the version to be published. Other contributors, especially those whose involvement in
TABLE 1 Overall online statistics for 2014 and 2013

\begin{tabular}{lll} 
Statistics & $2014^{\mathrm{a}}$ & 2013 \\
\hline total number of sessions & 61,402 & 72,233 \\
\hline total number of users & 49,775 & 58,749 \\
\hline total number of countries & 171 & 167 \\
\hline pageviews & 125,380 & 142,264 \\
\hline $\begin{array}{l}\text { average number of pages } \\
\text { per session }\end{array}$ & 2.04 & 1.97 \\
\hline average session duration & $00: 01: 38$ & $00: 01: 40$ \\
\hline
\end{tabular}

a from January 1 to December 9

the study was limited to the acquisition of funding, collection of data, or general supervision of the research group alone, should be listed in the Acknowledgments section.

The Internet is an important tool for delivering research findings published in medical journals. We have recently analyzed the online statistics for the Pol Arch Med Wewn to elucidate trends in this key aspect of journal visibility today. The overall statistics for the years 2013 and 2014 are shown in TABLE 1. As expected, over the last 2 years, the majority of users visited our website via external referrals such as PubMed followed by Google (FIGURE 1). The total number of journal pageviews has been stable over the last years with the maximum of over 70,000 unique entries recorded in 2013 and about 15\% less recorded for the period from January until December 9, 2014 (FIGURE 2). Of interest, readers from 171 countries looked up our open-access papers in 2014, which is 4 more than throughout the entire 2013. Not surprisingly, Poland has been number one on the list of the top 10 countries from which investigators and clinicians got access to read our articles, followed by the United States and China (FIGURES 3 and 4).

New visitors interested in the papers published in the Pol Arch Med Wewn constitute about $80 \%$ of the whole population of our readers with no difference between the results in 2013 and 2014 (FIGURE 5).

The top 3 papers published in the Pol Arch Med Wewn based on the total number of views in 2014 
FIGURE 1 Top 5 most common sources of visits in 2013 and 2014 a from January 1 to December 9
FIGURE 2 Total number of sessions in the years 2012 to 2014 a from January 1 to December 9
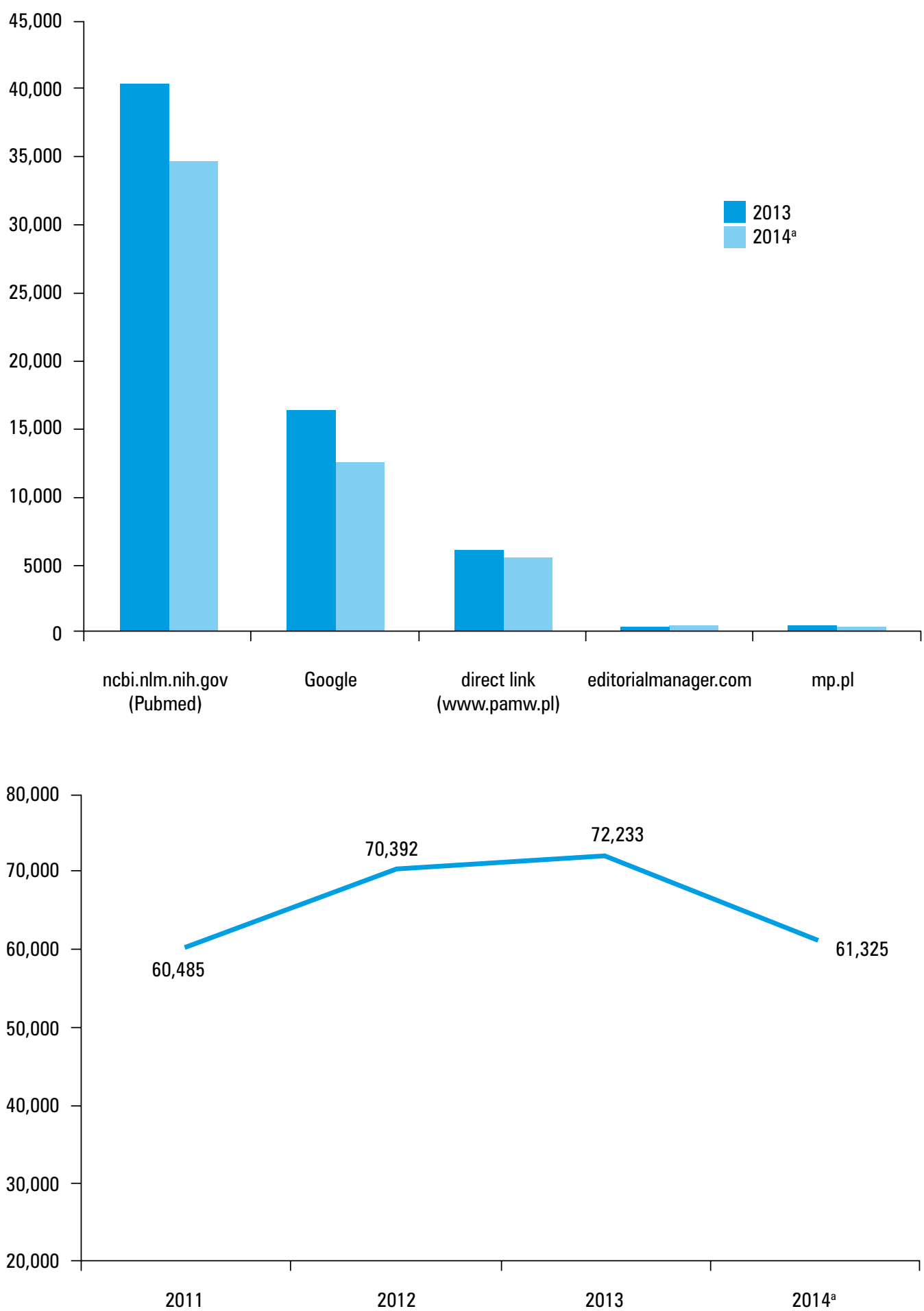

(until December 9) were 3 reviews addressing clinically relevant issues (TABLE 2). ${ }^{1-3}$ The most viewed paper by Sarr ${ }^{1}$ published in 2013 was also well cited (7 cites). The 2 other papers, ranked second and third, have gained considerably less cites so far, indicating that the number of views does not necessarily translate to a large number of investigators ready to refer to our articles in their scientific papers.

Last but not least, what does it mean to be a responsible editor of a scientific peer-reviewed journal in Poland, as in many other countries, in the era of an economic crisis and increasing demand to achieve commercial success? The owners of the journal, eg, a society, foundation, or company, have the right to appoint and dismiss the editor-in-chief and to make important business decisions, which could involve the editor if needed. Publishers should not interfere in the evaluation, selection, or editing of individual articles. The editor-in-chief must have full authority over the content of the journal. The concept of editorial freedom should be defended by the editor-in-chief supported by his or her devoted team, even if it requires placing their positions at stake. To secure this independence in everyday practice, all the efforts and risk should be undertaken. The editor-in-chief should be free to express critical views about all the submitted manuscripts without fear of retribution, even if his or her opinions are in 
FIGURE 3 Page entries per country: top 10 countries in 2014 (until December 9)

FIGURE 4 Page entries per country: top 10 countries in 2013

FIGURE 5 Proportion of new and returning visitors in 2013 (A) and 2014 (until December 9) (B)

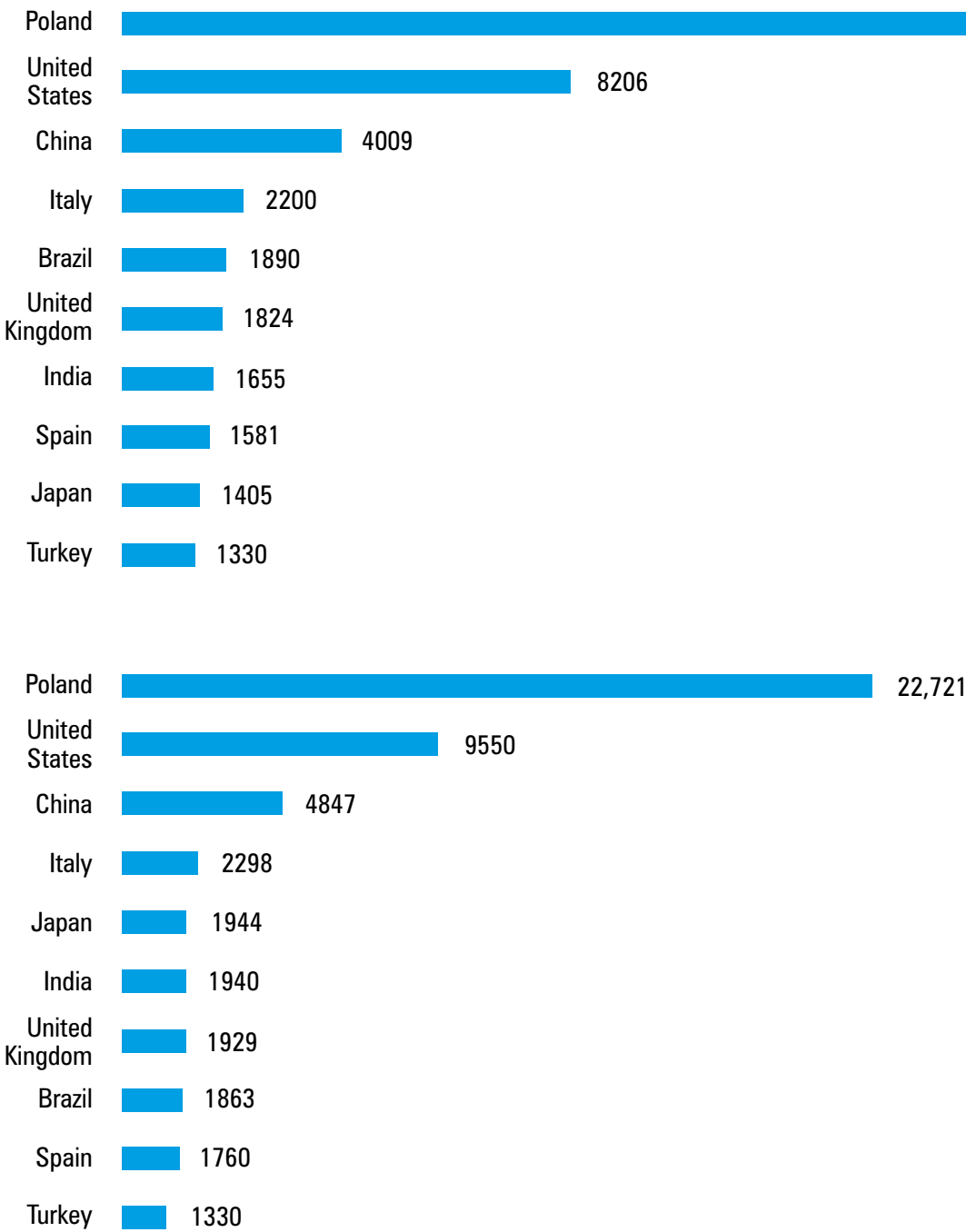

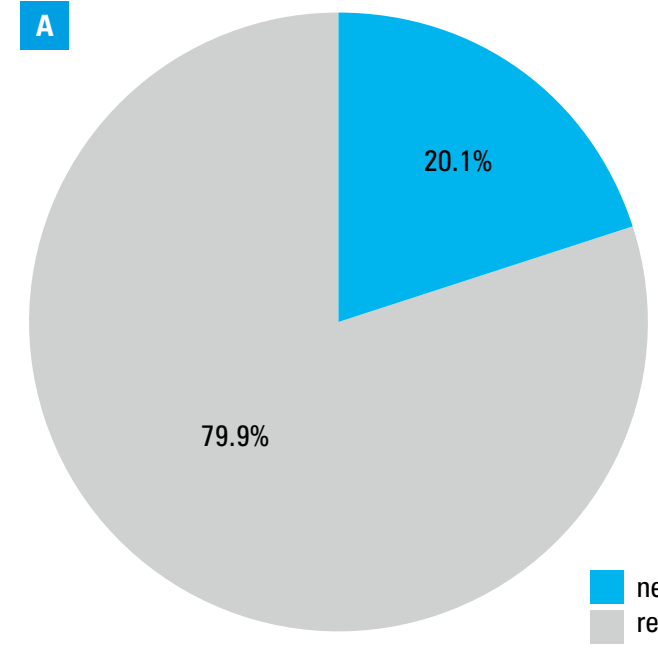

new visitors returning visitors

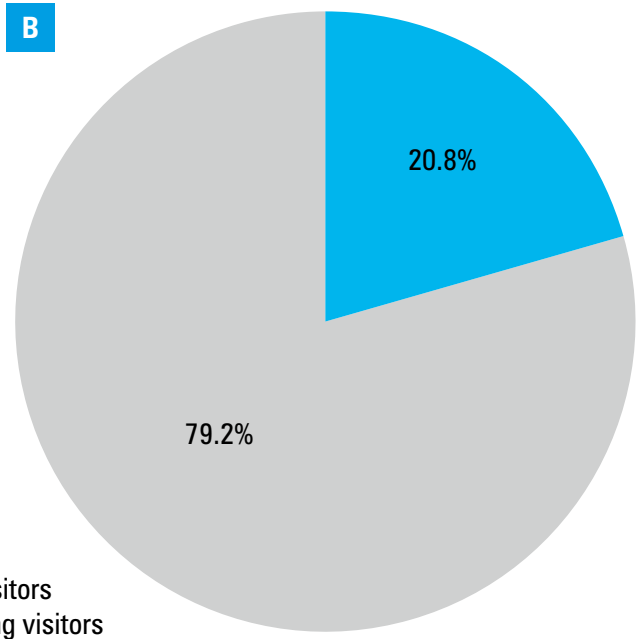

conflict with the commercial goals of the publisher. A scientific advisory board may be useful in helping the editorial team establish and maintain editorial policy. The national and international boards of our journal, including new eminent investigators selected and invited to join each year, is an important component of the whole editorial policy aimed at improving our standing among Polish biomedical journals.
We will be pleased to invite you to contribute your valuable research papers to the Pol Arch Med Wewn with a current IF of 2.052. With a steadily increasing number of citations in 2014, we estimate that our 2014 impact factor will be similar or slightly higher than the current value.

In the November issue of our journal, a controversial article by Gøtzsche ${ }^{4}$ was published. The views presented in this paper have attracted a 
TABLE 2 Top 10 articles viewed in 2014

1 Sarr MG. 2012 revision of the Atlanta classification of acute pancreatitis. Pol Arch Med Wewn. 2013; 123: 118-124.

2 Pandharipande PP, Patel MB, Barr J. Management of pain, agitation, and delirium in critically ill patients. Pol Arch Med Wewn. 2014; 124: 114-123.

3 Konduracka E, Krzemieniecki K, Gajos G. Relationship between everyday use cosmetics and female breast cancer. Pol Arch Med Wewn. 2014; 124: 264-269.

4 Staszel T, Zapała B, Polus A, et al. Role of microRNAs in endothelial cell pathophysiology. Pol Arch Med Wewn. 2011; 121: 361-366.

5 Iba T, Yamada A, Hashiguchi N, Nagaoka I. New therapeutic options for patients with sepsis and disseminated intravascular coagulation. Pol Arch Med Wewn. 2014; 124: 321-328.

6 Ratajczak MZ, Jadczyk T, Pędziwiatr D, Wojakowski W. New advances in stem cell research: practical implications for regenerative medicine. Pol Arch Med Wewn. 2014; 124: 417-426.

7 Kreatsoulas C, Anand SS. Menopausal hormone therapy for the primary prevention of chronic conditions. U.S. Preventive Services Task Force recommendation statement. Pol Arch Med Wewn. 2013; 123: 112-117.

8 Undas A, Pasierski T, Windyga J, Crowther M. Practical aspects of new oral anticoagulant use in atrial fibrillation. Pol Arch Med Wewn. 2014; 124: 124-135.

9 Alhazzani W, Alshahrani M, Moayyedi P, Jaeschke R. Stress ulcer prophylaxis in critically ill patients: review of the evidence. Pol Arch Med Wewn. 2012; 122: 107-114.

10 Marchetti T, Cohen M, Gris JC, de Moerloose P. Diagnosis and management of obstetrical antiphospholipid syndrome: where do we stand? Pol Arch Med Wewn. 2013; 123: 713-720. considerable interest since the impact of pharmaceutical industry on the market and health spending has been widely discussed both in the scientific literature and wider media. In response to a number of requests to publish this article in Polish, the Polish version has been attached to this issue. We hope that the current publication will encourage all readers to critically discuss its content and comment on it also in Poland, highlighting several differences between low-, middle-, and high-income countries within a broad spectrum of issues addressed by Gøtzsche. ${ }^{4}$

As an editorial team and members of the Polish Society of Internal Medicine, we are interested to learn about your views and encourage you to share your comments on the journal's content. With the support of our readers, we can continue to improve the quality of the Pol Arch Med Wewn and strive to reach even wider community of clinicians and basic scientists worldwide. We hope that you will find our journal useful for your research and continued education.

We wish you Merry Christmas and a Happy New Year 2015!

\section{REFERENCES}

1 Sarr MG. 2012 revision of the Atlanta classification of acute pancreatitis. Pol Arch Med Wewn. 2013; 123: 118-124.

2 Pandharipande PP, Patel MB, Barr J. Management of pain, agitation, and delirium in critically ill patients. Pol Arch Med Wewn. 2014; 124: 114-123.

3 Konduracka E, Krzemieniecki K, Gajos G. Relationship between everyday use cosmetics and female breast cancer. Pol Arch Med Wewn. 2014; 124: 264-269.

4 Gøtzsche PC. Our prescription drugs kill us in large numbers. Pol Arch Med Wewn. 2014; 124: 628-634. 